\title{
Credit risk transfer and contagion ${ }^{\text {is }}$
}

\author{
Franklin Allen ${ }^{\mathrm{a}, *}$, Elena Carletti ${ }^{\mathrm{b}}$ \\ ${ }^{a}$ University of Pennsylvania, USA \\ ${ }^{\mathrm{b}}$ Center for Financial Studies, Germany
}

Received 9 October 2005; accepted 27 October 2005

\begin{abstract}
Some have argued that recent increases in credit risk transfer are desirable because they improve the diversification of risk. Others have suggested that they may be undesirable if they increase the risk of financial crises. Using a model with banking and insurance sectors, we show that credit risk transfer can be beneficial when banks face uniform demand for liquidity. However, when they face idiosyncratic liquidity risk and hedge this risk in an interbank market, credit risk transfer can be detrimental to welfare. It can lead to contagion between the two sectors and increase the risk of crises.
\end{abstract}

(C) 2005 Elsevier B.V. All rights reserved.

JEL classification: G21; G22

Keywords: Financial innovation; Pareto inferior; Banking; Insurance

\section{Introduction}

It is often argued that financial innovation in the form of creating new instruments and opening up new markets is desirable because it creates opportunities for diversification and potentially promotes liquidity. Although this argument appears to be a powerful one, practical experience of financial liberalization such as the introduction of new instruments

\footnotetext{
${ }^{2}$ Prepared for the Carnegie-Rochester Conference on Financial Innovation, Risk, and Fragility held on April 15 and 16, 2005. We are grateful to participants and particularly to our discussant, Tano Santos, for very helpful comments and suggestions. We also thank James Thompson for his comments.

${ }^{*}$ Corresponding author. Tel.: +12158983629 ; fax: + 12155732207.

E-mail addresses: allenf@wharton.upenn.edu (F. Allen), carletti@ifk-cfs.de (E. Carletti).
} 
and the creation of new markets has not always been positive, particularly in emerging markets. Such changes have often led to financial crises.

This paper is concerned with credit risk transfer. This has existed for many years, but recent innovations such as credit derivatives have increased the amount that it occurs. Table 1 (BIS, 2003) shows the size of credit risk transfer markets using various instruments from 1995 to 2002. It can be seen that the use of all types of credit risk transfer has increased substantially. The growth has been particularly rapid in credit derivatives and collateralized debt obligations. Studies by the British Bankers Association (BBA, 2002)

Table 1

Size of credit risk transfer markets (in billions of US \$)

\begin{tabular}{|c|c|c|c|c|c|c|c|c|}
\hline Instrument & 1995 & 1996 & 1997 & 1998 & 1999 & 2000 & 2001 & 2002 \\
\hline \multicolumn{9}{|l|}{ Loan trading (turnover) } \\
\hline $\begin{array}{l}\text { US market } \\
\text { (Loan Pricing Corporation) }\end{array}$ & 34 & 40 & 61 & 78 & 79 & 102 & 118 & $117^{\mathrm{a}}$ \\
\hline \multicolumn{9}{|l|}{ Credit derivatives (outstanding) } \\
\hline BIS triennial survey & & & & 108 & & & 693 & \\
\hline $\mathrm{US} \mathrm{OCC}^{\mathrm{b}}$ & & & & 144 & 287 & 426 & 395 & $492^{c}$ \\
\hline British Bankers Association & & & 180 & 350 & 586 & 893 & 1189 & $1952^{\mathrm{d}}$ \\
\hline Risk Magazine & & & & & & 810 & 1398 & \\
\hline ISDA & & & & & & & 919 & $1600^{\mathrm{d}}$ \\
\hline \multicolumn{9}{|l|}{ Asset-backed securities } \\
\hline $\begin{array}{l}\text { US market (outstanding) } \\
\text { (Bond Market Association) } \\
\text { European market (issuance) }\end{array}$ & 315 & 403 & 517 & 684 & 816 & 947 & 1114 & $1258^{\mathrm{f}}$ \\
\hline (Moody's) $^{\mathrm{g}}$ & & & & & 68 & 80 & 134 & $50^{\mathrm{h}}$ \\
\hline $\begin{array}{l}\text { Australian market (outstanding) } \\
\text { (Australian Bureau of Statistics) }\end{array}$ & 7 & 10 & 15 & 19 & 27 & 33 & 38 & 54 \\
\hline \multicolumn{9}{|l|}{ Collateralized debt obligations } \\
\hline $\begin{array}{l}\text { US market (outstanding) } \\
\text { (BondMarket Association) } \\
\text { European market (issuance) }\end{array}$ & 1 & 1 & 19 & 48 & 85 & 125 & 167 & $232^{f}$ \\
\hline (Moody’s) & & & & & 42 & 71 & 114 & $70^{\mathrm{h}}$ \\
\hline $\begin{array}{l}\text { Total bank credit } \\
\quad \text { (outstanding) }^{\mathrm{j}} \\
\text { IMF }\end{array}$ & 23,424 & 23,576 & 23,309 & 26,018 & 26,904 & 27,221 & 27,442 & $29,435^{\mathrm{i}}$ \\
\hline $\begin{array}{l}\text { Corporate debt securities }{ }^{\mathrm{k}} \\
\text { (outstanding) } \\
\text { BIS }\end{array}$ & 3241 & 3373 & 3444 & 4042 & 4584 & 4939 & 5233 & $5505^{\mathrm{i}}$ \\
\hline
\end{tabular}

${ }^{\text {a }}$ First three quarters of 2002, annualized.

${ }^{\mathrm{b}}$ Holdings of US commercial banks.

${ }^{\mathrm{c}}$ Second Quarter of 2002.

${ }^{\mathrm{d}}$ Forecast for 2002.

${ }^{\mathrm{e}}$ Excluding CBOs/CDOs.

${ }^{\mathrm{f}}$ September 2002.

${ }^{\mathrm{g}} \mathrm{ABSs}$ and MBSs.

${ }^{\mathrm{h}}$ First half of 2002.

i June 2002.

${ }^{\mathrm{j}}$ Domestic and international credit to non-bank borrowers (United States, United Kingdom, Japan, Canada, Euro area).

${ }^{\mathrm{k}}$ Debt securities issued in international and domestic markets, non-financial corporates. 
and Fitch Ratings (2003) indicate that banks are the major participants both as buyers and sellers in the markets for credit risk transfer. Overall banks are net buyers and insurance companies are net sellers.

We show how financial innovation in the form of new credit risk transfer instruments can lead to beneficial diversification in some circumstances but to a fall in welfare through the creation of contagion in others. This argument is developed in a model with a banking sector and an insurance sector based on Allen and Gale (2005a). Both sectors are competitive and can buy risk-free short and long assets. The difference between the two sectors is that banks can make risky loans to firms, while insurance companies insure another group of firms whose assets may be damaged. Also, banks raise funds in the form of deposits and capital, while insurance companies have as funds only the premiums they receive from the firms they insure.

We start by considering the case where all banks face the same demand for liquidity from their depositors. When both sectors are autarkic so they operate without links, banks and insurance companies hold different assets and only the insurance sector is subject to systemic risk. If the return on the risk-free long asset is low compared to the return on the risky loans, banks invest in the short term asset to repay their early depositors and in risky loans. Insurance companies offer partial insurance, and invest the premiums they initially receive in the short asset. Since there is aggregate risk in the insurance sector, insurance companies may not be able to repair all damaged assets and so go bankrupt. This systemic risk is benign in the sense that there are no deadweight costs associated with it.

In the case where all banks face the same demands for liquidity from their depositors, credit risk transfer between the banking and insurance sectors is beneficial. Specifically, it allows the risk the two sectors face to be shared without creating contagion because the two sectors still hold different assets. As in autarky, banks invest in the short asset and in risky loans. By contrast, insurance companies now also hold the long asset to facilitate their ability to transfer risks; and they are forced to liquidate it when the firms they are insuring have high losses. The price they receive for the long asset is very low to ensure there are adequate incentives for providing liquidity to the market. This implies that insurance companies may still not be able to pay all firms with damaged assets and go bankrupt. Importantly though, this low price does not affect the banking sector because banks do not use the long asset. Credit risk transfer is then desirable because its only effect is to allow diversification of risk between the banking and the insurance sectors.

The effect of introducing the credit risk transfer differs when banks face idiosyncratic liquidity risk. In this case, some banks have a large number of early consumers who withdraw at the intermediate date and other banks have a large number of late consumers who withdraw at the final date. Banks can hedge this risk by holding the risk-free long asset and trading it in a liquid market. If a bank has a large number of early consumers, it can sell the long asset to banks with a large number of late consumers. Since there is assumed to be no aggregate liquidity risk, in the autarkic equilibrium only insurance companies face systemic risk. As before, they invest the premiums they receive in the short asset, and go bankrupt when the firms they insure experience high losses. The banking sector experiences no crises and banks hedge their idiosyncratic liquidity risk using the market for long term assets.

However, since banks now hold the long term asset, introducing credit risk transfer can be damaging because of the possibility of contagion. The insurance sector again uses the long asset to allow it to undertake its credit risk transfers effectively. When insurance companies 
face a shock where their losses are high, they will be forced to liquidate the long asset. This liquidation forces down the price. The reason is that there is "cash in the market pricing". The buyers optimally use all of their liquidity and sellers supply all of their holdings. The price is the ratio of the two. If the quantity sold goes up, the price goes down. This fall in price now affects the banking industry as banks are using the long asset to hedge their idiosyncratic liquidity risk. There is then the possibility of damaging contagion of systemic risk to the banking sector. Although taking prices as given it is optimal to engage in credit risk transfer, the equilibrium with credit risk transfer can be Pareto worse than the autarkic equilibrium. The systemic risk is costly since banks' loans cannot be liquidated for a positive amount and the contagion interferes with the risk sharing between banks with different proportions of early and late consumers through the interbank market.

There is a small but growing literature on credit risk transfer. The first strand of this literature considers the impact of credit risk transfer on the allocation of resources when there is asymmetric information. Morrison (2005) shows that a market for credit derivatives can destroy the signalling role of bank debt and lead to an overall reduction in welfare as a result. He suggests that disclosure requirements for credit derivatives can help offset this effect. Nicolo and Pelizzon (2004) show that if there are banks with different abilities to screen borrowers, then good banks can signal their type using first-to-default basket contracts that are often used in practice. These involve a payment to the protection buyer if any of a basket of assets defaults. Only protection sellers with very good screening abilities will be prepared to use such contracts. Chiesa (2004) considers a situation where banks have a comparative advantage in evaluating and monitoring risks but limited risk bearing capacity. Credit risk transfer improves efficiency by allowing the monitored debt of large firms to be transferred to the market while banks can use their limited risk bearing capacity for loans to small businesses. Arping (2004) considers the change in lender and borrower incentives when credit risk is transferred. He shows that lenders will be more willing to call loans but will be less willing to provide monitoring effort. Effective incentives can be provided by designing the maturity structure of credit protection appropriately. Parlour and Plantin (2005) consider the effect of credit risk transfer on relationship banking. Banks can receive proprietary information about loan quality or can have a shock to their discount factor. Either can cause them to try to transfer the risk and this creates an adverse selection problem. Parlour and Plantin identify when credit risk transfer markets arise and whether this is efficient. In contrast to these papers, our paper focuses on the situation where there is symmetric information and shows how credit risk transfer can improve the allocation of resources through better risk sharing across sectors.

The second part of the literature focuses on the stability aspects of credit risk transfer. Wagner and Marsh (2004) consider the transfer of risk between banking and non-banking sectors. They find that the transfer of risk out of a relatively fragile banking sector leads to an improvement in stability. Wagner (2005a) develops a model where credit risk transfer improves the liquidity of bank assets. However, this can increase the probability of crises by increasing the risks that banks are prepared to take. Wagner (2005b) shows that the increased portfolio diversification possibilities introduced by credit risk transfer can increase the probability of liquidity-based crises. The reason is that the increased diversification leads banks to reduce the amount of liquid assets they hold and increase the amount of risky assets. In contrast to these contributions, in our paper the focus is on idiosyncratic liquidity shocks and their interaction with credit risk transfer in creating contagion between banking and insurance systems. 
The paper also contributes to the literature on financial innovation. Hart (1975) shows that with incomplete markets, the introduction of a new market can lead to a Pareto reduction in welfare. Since then a number of authors have shown that financial innovation can be bad for welfare (see, e.g., Newbery and Stiglitz, 1984; Allen and Gale, 1990; Elul, 1995; and Cass and Citanna, 1998). The most closely related paper in this context is Duffee and Zhou (2001). They show that credit risk transfer can cause the collapse of other risk sharing mechanisms such as the loan-sale market, and this can result in a reduction in welfare. The credit risk transfer market attracts some participants from the loan-sale market and this worsens the adverse selection problem in the latter to such an extent that it collapses. In contrast, our paper shows that credit risk transfer can cause contagion and the spread in systemic risk makes everybody worse off.

The rest of the paper proceeds as follows. Section 2 develops a model with a banking and an insurance sector. Section 3 shows how credit risk transfer can improve welfare relative to the autarkic equilibrium through better risk sharing. Section 4 describes the detrimental effect of credit risk transfer when banks are subject to idiosyncratic liquidity shocks. Section 5 contains concluding remarks.

\section{The model}

The model is based on the analyses of crises and systemic risk in Allen and Gale (1998, 2000a-c, 2004a, b, 2005b) and Gale (2003, 2004), and particularly in Allen and Gale (2005a). A standard model of intermediation is extended by adding an insurance sector. Since the risks faced by the insurance sector are not perfectly correlated with the risks faced by the banking sector, there is scope for diversification. This is the basic motive for credit risk transfer.

There are three dates $t=0,1,2$ and a single, all-purpose good that can be used for consumption or investment at each date. There are two sectors in the financial system, the banking sector and the insurance sector. Each sector consists of a large number of competitive firms and the lines of business of banks and insurance companies do not overlap. This is a strong assumption but a necessary one, since the combination of insurance and intermediation activities in a single financial institution would obviate the need for credit risk transfer outside the institution.

There are two securities, one short and one long. The short security is represented by a storage technology: one unit at date $t$ produces one unit at date $t+1$. The long security is represented by a constant-returns-to-scale investment technology that takes two periods to mature: one unit invested in the long security at date 0 produces $R>1$ units of the good at date 2 (and nothing at date 1). These securities represent the investment opportunities that banks and insurance companies have in common. In practice there are many such securities, for example, government and other bonds.

In addition to the short and long securities, banks and insurance companies have distinct direct investment opportunities. Banks can make loans to firms which succeed with probability $\beta$. More precisely, each firm borrows one unit at date 0 and invests in a risky venture that produces $B_{H}$ units of the good at date 2 if successful and $B_{L}$ if unsuccessful. There is assumed to be an infinite supply of such firms, so that banks take all the surplus on the loan market.

Banks raise funds from depositors, who have one unit of the good at date 0 and none at dates 1 and 2. Depositors are uncertain of their preferences: with probability $\lambda$ they are 
early consumers, who only value the good at date 1 and with probability $1-\lambda$ they are late consumers, who only value the good at date 2 . Uncertainty about time preferences generates a preference for liquidity and a role for the intermediaries as providers of liquidity insurance. The utility of consumption is represented by the function $U(c)$ with the usual properties. We normalize the number of consumers to 1. Since banks compete to raise deposits, they choose the contracts they offer to maximize depositors' expected utility. If they failed to do so, another bank could step in and offer a better contract to attract away all their customers.

Insurance companies sell insurance to a large number of firms, whose measure is normalized to one. Each firm has one unit of endowment at date 0 and owns an asset that produces $A$ units of the good at date 2. With probability $\alpha$ the asset suffers some damage at date 1. Unless this damage is repaired, at a cost of $\gamma$, the asset becomes worthless and will produce nothing at date 2 . Thus, firms can decide to buy insurance against the probability of incurring the damage in exchange for a premium at date 0 . The insurance companies collect the premiums and invest them in the short security at date 0 in order to pay the firms' damages at date 1 . The owners of the firms consume at date 2 and have a utility function $V(C)$ with the usual properties. Similarly to the banks, the insurance companies operate in competitive markets and thus maximize the expected utility of the owners of the firms. If they did not do this, another firm would enter and attract away all their customers.

Finally, we introduce a class of risk neutral investors who can provide capital to the insurance and banking sectors. Investors have a large (unbounded) amount of the good $W_{0}$ as endowment at date 0 and nothing at dates 1 and 2 . They provide capital to the intermediary through the contract $e=\left(e_{0}, e_{1}, e_{2}\right)$, where $e_{0} \geqslant 0$ denotes an investor's supply of capital at date $t=0$, and $e_{t} \geqslant 0$ denotes consumption at dates $t=1,2$. Although investors are risk neutral, we assume that their consumption must be non-negative at each date. Otherwise, they could absorb all risk and provide unlimited liquidity. The investors' utility function is then defined as

$$
u\left(e_{0}, e_{1}, e_{2}\right)=\rho W_{0}-\rho e_{0}+e_{1}+e_{2},
$$

where the constant $\rho$ is the investors' opportunity cost of funds. This can represent their time preference or their alternative investment opportunities that are not available to the other agents in the model. We assume $\rho>R$ so that it is not worthwhile for investors to just invest in assets at date 0 . This has two important implications. First, since investors have a large endowment at date 0 and the capital market is competitive, there will be excess supply of capital and they will just earn their opportunity cost. Secondly, the fact that investors have no endowment (and non-negative consumption) at dates 1 and 2 implies that their capital must be converted into assets in order to provide risk sharing at dates 1 and 2 .

For the purposes of illustrating the scope for diversification, the structure of uncertainty is one that allows for some diversification and some aggregate risk. This is achieved by assuming that the proportions of successful firms for the banking sector and of damaged firms for the insurance sector equal the probabilities $\beta$ and $\alpha$, respectively, and that these probabilities are themselves random. In particular, $\beta$ and $\alpha$ take two values each, $\beta_{H}$ and $\beta_{L}$ and $\alpha_{H}$ and $\alpha_{L}$. Note also that $\beta$ and $\alpha$ are independent so that we have four possible states, $\left(\beta_{H}, \alpha_{H}\right),\left(\beta_{H}, \alpha_{L}\right),\left(\beta_{L}, \alpha_{H}\right),\left(\beta_{L}, \alpha_{L}\right)$. We denote them simply as $H H, H L, L H$, and $L L$, respectively. This simple structure is enough to illustrate the main points, and nothing would change with a more general structure. All uncertainty is resolved at the beginning of 
date 1. Banks discover whether loans will pay off or not at date 2. Depositors learn whether they are early or late consumers. Insurance companies learn which firms have damaged assets.

\section{Beneficial credit risk transfer}

The purpose of this section is to show that credit risk transfer can be beneficial as it allows risk sharing across sectors. This is demonstrated using numerical examples. The first case considered is when the banking sector and the insurance sector are autarkic and operate separately.

\subsection{The autarkic banking sector}

The return on the long asset is $R=1.25$. Depositors become early consumers with probability $\lambda=0.5$ and have utility function $U(c)=\operatorname{Ln}(c)$. Loans pay off $B_{H}=1.75$ with probability $\beta_{H}=1$ in state $H$, which occurs with probability 0.7 ; and $B_{L}=0.75$ with probability $1-\beta_{L}=1$ in state $L$, which occurs with probability 0.3 . The expected payoff on loans is then $0.7 \times 1.75+0.3 \times 0.75=1.45$.

\subsubsection{No capital}

In order to understand the role of capital in the model, it is helpful to start with the case where there is no capital. Since banks are competitive, they choose the contracts they offer to maximize depositors' expected utility. At date 0 banks choose how to split their 1 unit of deposits investing $x$ units in the short term asset, $y$ units in the long asset, and $z$ units in loans. Since ex ante all banks are identical, they choose $x, y$, and $z$ to solve the following problem:

$$
\begin{aligned}
\operatorname{Max} & 0.5 U\left(c_{1}\right)+0.5\left[0.7 U\left(c_{2 H}\right)+0.3 U\left(c_{2 L}\right)\right] \\
\text { s.t. } & \\
& x+y+z=1 \\
& c_{1}=\frac{x}{0.5} \\
& c_{2 H}=\frac{y R+z B_{H}}{0.5} \\
& c_{2 L}=\frac{y R+z B_{L}}{0.5} .
\end{aligned}
$$

Each bank has 1 unit of depositors and 0.5 of them become early consumers. The first term in the objective function represents the utility $U\left(c_{1}\right)$ of the 0.5 early consumers. The bank uses the proceeds of the short term asset to provide them with a level of consumption $c_{1}=x / 0.5$. The second term represents the 0.5 depositors who become late consumers. With probability 0.7 the banks' loans pay off $B_{H}$ and the late consumers receive consumption $c_{2 H}=\left(y R+z B_{H}\right) / 0.5$. With probability 0.3 the banks' loans pay off $B_{L}$ and the late consumers receive consumption $c_{2 L}=\left(y R+z B_{L}\right) / 0.5$. The constraint (2) is the budget constraint at date 0 . 
It can be shown using direct numerical hill-climbing techniques that the optimal solution in this case is

$$
\begin{aligned}
& x=0.5, \quad y=0, \quad z=0.5, \\
& c_{1}=1, \quad c_{2 H}=1.75, \quad c_{2 L}=0.75, \\
& E U=0.153 .
\end{aligned}
$$

Banks use the short term asset to provide consumption to the early consumers. It is not worth them using the long asset. The expected return of 1.45 on loans is sufficiently greater than the return of 1.25 on the long asset that banks put nothing in the latter. Note also that the late consumers have an expected consumption at date 2 equal to $E c_{2}=0.7 c_{2 H}+0.3 c_{2 L}=1.45$. As we will see shortly, this will be lower when we introduce capital.

\subsubsection{With capital}

Next consider what happens when there are investors who can make an amount of capital $e_{0}$ available to the banks. Their opportunity cost for providing this equity capital is $\rho=1.5$. Since investors are indifferent between consumption at date 1 and date 2 , it is optimal to set $e_{1}=0$, invest $e_{0}$ in the long asset or loans, and make a payout $e_{2}$ at date 2 to investors.

Banks' optimization problem is the same as before except now the budget constraint at date 0 is

$$
x+y+z=1+e_{0},
$$

rather than (2). This reflects the fact that, in addition to the depositors' endowment of 1 , banks can now also invest the investors' contribution of $e_{0}$. Banks have to pay $e_{2}$ at date 2 to investors to compensate for supplying the capital. It is best to make this payment in state $H$ when loans pay off $B_{H}$ and depositors' marginal utility of consumption is lowest. Thus, (4) is replaced by

$$
c_{2 H}=\frac{y R+z B_{H}-e_{2}}{0.5} .
$$

In order for the risk neutral investors to be willing to supply the capital, $e_{0}$, they must receive an expected payoff equal to their opportunity cost $e_{0} \rho$. Since $e_{2}$ is paid when state $H$ occurs, which happens 0.7 of the time, it is necessary that

$$
e_{0} \rho=0.7 e_{2} \text {. }
$$

The optimal solution in this case is

$$
\begin{aligned}
& x=0.5, \quad y=0, \quad z=0.818, \quad e_{0}=0.318, \quad e_{2}=0.682, \\
& c_{1}=1, \quad c_{2 H}=1.5, \quad c_{2 L}=1.227, \\
& E U=0.173 .
\end{aligned}
$$

Comparing this to the previous optimum without capital allows us to see the role of capital. The providers of capital are risk neutral. They only receive a payment $e_{2}$ when banks' loans pay off $B_{H}=1.75$. In return for this payment, investors provide capital of $e_{0}=0.318$, and banks use this to make more loans. Again it is not worth banks investing 
anything in the long asset because its payoff is too low compared to the expected payoff of the loans. Overall, capital allows banks to reduce the variance of the payments to depositors in the second period. Instead of $c_{2 H}=1.75$, and $c_{2 L}=0.75$ without capital, depositors now receive $c_{2 H}=1.5$, and $c_{2 L}=1.227$. In effect, the late consuming depositors are sharing risk with the investors. This risk sharing comes at a cost, however. The opportunity cost of the investors providing the capital is $\rho=1.5$, which is greater than the expected return on loans of 1.45 . The expected consumption $E c_{2}=0.7 c_{2 H}+0.3 c_{2 L}$ of the late consuming depositors is thus reduced from 1.45 to 1.418 . Their expected utility, though, is increased from 0.153 to 0.173 . The fact that the opportunity cost of the capital provided by the investors is above the return on loans means that capital is costly and is only used for partial rather than complete risk sharing.

\subsection{The autarkic insurance sector}

The insurance sector is considered next on its own. For simplicity, we consider here the case where there is no market for liquidating the long asset. It can be shown (see below), however, that at the equilibrium prices that would ensure a supply of liquidity, the autarkic equilibrium in the insurance sector would be unaltered if such a market was included.

As explained above, insurance companies offer insurance to firms against the probability that their assets are damaged at date 1 and need to be repaired in order to produce $A$ at date 2. In our example, the probability of such damage is $\alpha_{H}=0.5$ in state $H$, which occurs with probability 0.9 , and $\alpha_{L}=1$ in state $L$, which occurs with probability 0.1 . Assets produce $A=1.35$ at date 2 and repairing them when damaged $\operatorname{costs} \gamma=1$ at date 1 . The utility function of the owners of the firm is $V(c)=\operatorname{Ln}(c)$.

The insurance industry is competitive so the insurance companies do not earn any profits. Similarly to the banks, they maximize the expected utility of the owners of the firms they insure. They can offer partial or full insurance to firms. If they offer partial insurance, they charge a premium equal to 0.5 at date 0 to the firms so that the latter still have another 0.5 of their initial endowment to invest. Firms will find it optimal to invest this 0.5 in the long asset rather than the short asset since their owners do not consume until date 2 . In order to have funds to repair the damaged assets, insurance companies must invest in the short asset so that they have liquidity at date 1 . In state $H$ they need funds $\alpha_{H} \gamma=0.5$ at date 1 for claims to repair the damaged assets so they put $X=0.5$ in the short asset and $Y=0$ in the long asset. This means they have funds of 0.5 at date 1 and can pay all the claims to repair the damaged assets. With insurance the firms' assets will pay off $A$ for sure in this state. Given this and the fact that the firms' owners invest 0.5 in the long asset, their consumption in state $H$ is $C_{2 H}=A+0.5 R=1.975$. In state $L$ the insurance companies receive claims of $\alpha_{L} \gamma=1$. They do not have sufficient funds to pay these so they go bankrupt. With partial insurance there is thus systemic risk in the insurance industry. When insurance companies go bankrupt, their assets are distributed equally among the claimants. The firms receive 0.5 from the insurance companies' liquidation of the short term assets, but cannot repair their assets so these produce nothing. The consumption of the owners of the firms is therefore $C_{2 L}=0.5+0.5 R=1.125$. Their expected utility with partial insurance is then

$$
E V_{\text {partial }}=0.9 V(A+0.5 R)+0.1 V(0.5+0.5 R)=0.624 \text {. }
$$

If the insurance companies offered full insurance, they would charge 1 at date 0 . They would invest all of this in the short term asset and could meet all of their claims in both states. Now, 
however, the firms' owners would have nothing left over at date 0 and would hold no investments of their own. In state $H$ the insurance companies would only use 0.5 of their assets at date 1 to repair their customers' machines and would have 0.5 left over. Since the industry is competitive they would pay this out to the insured firms. Hence $C_{2 H}=A+0.5=1.85$. In state $L$ all the insurance companies' funds are used to repair their customers' machines and $C_{2 L}=A$. In this case the expected utility of the firms' owners would be

$$
E V_{\text {full }}=0.9 V(A+0.5)+0.1 V(A)=0.584 \text {. }
$$

Partial insurance is thus superior to full insurance. It can readily be checked that partial insurance is also better for the firms than self insurance. Thus the optimal scheme for the insurance industry is to partially insure firms and offer the owners of the firms an expected consumption at date 2 equal to $E C_{2}=0.9 C_{2 H}+0.1 C_{2 L}=1.890$. The firms put the remaining part of their endowment in the long asset. There is no point in the insurance company holding the long asset because there is no market for it when they go bankrupt. If a market is included as explained below, then it will still not be optimal for the insurance companies to hold the long asset because there is a liquidation cost while if the firms hold it directly there is none.

There is no role for capital in the insurance sector so their capital is $E_{0}=0$. Capital providers charge a premium to cover their opportunity cost $\rho=1.5$. Their funds would have to be invested in the short asset since it is not optimal to hold any long assets. There are already potentially enough funds from customers for insurance companies to hold more of the short asset but it is not efficient to do so. There is a small probability of a large loss and it is not worth holding enough short assets to guard against this contingency given the high opportunity cost of holding short assets. If the short assets are funded by capital and there is a premium to be paid for the capital it is even less efficient. Capital will not be used in the insurance industry unless there are regulations forcing this.

\subsection{Credit risk transfer}

In the previous sections the banking and insurance sectors have been considered in isolation. We now consider them together, and introduce the possibility for the long term asset to be liquidated in a market at date 1 . Since the risks in the two sectors are independent, we have four possible states for the probabilities $\beta$ and $\alpha$, which we describe as $H H, H L, L H$ and $L L$. The payoffs in these four states are given in Table 2.

It can be seen that the late consuming depositors have different payoffs in states $H H$ and $H L$ compared to states $L H$ and $L L$. Similarly the payoffs to the owners of the firms being insured are different in states $H H$ and $L H$ as compared to $H L$ and $L L$. These differences mean that there is potential for risk sharing between the two groups. Credit risk transfer between the two sectors represents one way of achieving this risk sharing.

Table 2

\begin{tabular}{|c|c|c|c|c|c|}
\hline State & Bank loans & Late depositors & Insurance claims $(\%)$ & Firms & Probability \\
\hline$H H$ & 1.75 & 1.5 & 50 & 1.975 & $0.7 \times 0.9=0.63$ \\
\hline$H L$ & 1.75 & 1.5 & 100 & 1.125 & $0.7 \times 0.1=0.07$ \\
\hline$L H$ & 0.75 & 1.227 & 50 & 1.975 & $0.3 \times 0.9=0.27$ \\
\hline$L L$ & 0.75 & 1.227 & 100 & 1.125 & $0.3 \times 0.1=0.03$ \\
\hline
\end{tabular}


For simplicity the focus is on a particularly simple form of risk transfer. Banks make a payment $\tau_{H L}$ to the insurance companies in state $H L$; and the insurance companies make a payment $\tau_{L H}$ to the banks in state $L H$. Notice that markets are still not complete with this credit risk transfer. For simplicity it is assumed that the banks' depositors obtain the surplus from the credit risk transfer. The insurance companies will compete to provide the credit risk transfer that maximizes the utility of the banks' depositors at the lowest cost to themselves. In equilibrium they will obtain their reservation utility, which is what they would receive in autarky.

How can such transfers be funded? In state $H L$ banks' loans pay off $B_{H}$ so they have a large amount of funds and can simply transfer some of these to the insurance companies. Banks still maximize the expected utility of depositors (1) subject to the constraints (6) and (8). The only difference is that now they have to pay $\tau_{H L}$ in state $H L$ to the insurance companies, and receive $\tau_{L H}$ in state $L H$. Thus, the per capita consumption of late consumers in these two states becomes

$$
\begin{aligned}
c_{2 H L} & =\frac{y R+z B_{H}-\tau_{H L}-e_{2}}{0.5}, \\
c_{2 L H} & =\frac{y R+z B_{L}+\tau_{L H}}{0.5} .
\end{aligned}
$$

The problem is more complex for the insurance companies. In state $L H$ the owners of the firms that insure their assets with the insurance companies have plenty of funds. However, the companies themselves do not. They are only holding enough to meet claims at date 1 in states $H H$ and $L H$. In order for them to be able to make a payout on the credit risk transfer to the banks at date 2 in state $L H$ they must hold extra assets. They must charge the firms more initially and the firms will consequently have to reduce their holdings of the long asset. If the insurance companies hold the short asset there is an opportunity cost of $R-1$ in all states. Let the transfer from the banks to the insurance companies in state $H L$ be $\tau_{H L}$, and the amount invested in the short asset to fund the transfer from the insurance companies to the banks in state $L H$ be $\sigma_{L H}=\tau_{L H}$. The opportunity cost in each state is $\sigma_{L H}(R-1)$. The expected utility of the insured firms' owners, which is ultimately the objective function of the insurance companies, is equal with partial insurance to

$$
\begin{aligned}
E V_{\text {short }}= & 0.63 V\left(A+\sigma_{L H}+\left(0.5-\sigma_{L H}\right) R\right) \\
& +0.07 V\left(0.5+\sigma_{L H}+\tau_{H L}+\left(0.5-\sigma_{L H}\right) R\right) \\
& +0.27 V\left(A+\left(0.5-\sigma_{L H}\right) R\right)+0.03 V\left(0.5+\sigma_{L H}+\left(0.5-\sigma_{L H}\right) R\right) .
\end{aligned}
$$

To see this, note that the firms pay an insurance premium $0.5+\sigma_{H L}$ to the insurance companies who invest it in the short asset. The firms then invest the amount that remains after they have paid the insurance premium, $\left(0.5-\sigma_{L H}\right)$, in the long asset, and this pays off $\left(0.5-\sigma_{L H}\right) R$ in every state. In state $H H$, which occurs with probability 0.63 , all the machines that are damaged are repaired using 0.5 of the proceeds from the short asset. The firms receive $A$ from their machines. There are no credit risk payments so the insurance companies pay the proceeds of their investment in the short asset, $\sigma_{L H}$, out to the firms (since the insurance market is competitive). In state $H L$, which occurs with probability 0.07, the insurance companies have all their customers claim and go bankrupt. They are unable to repair any machines and distribute the $0.5+\sigma_{L H}$ that was invested in the short asset to their customers. They receive a credit risk transfer payment of $\tau_{H L}$ from the banks 
which they also pay out to their customers. In state $L H$, which occurs with probability 0.27 , everything is the same as in state $H H$, except that the insurance companies must pay out $\tau_{L H}=\sigma_{L H}$ as a credit risk transfer payment to the banks instead of to their customers. Finally in state $L L$, which occurs with probability 0.03 , everything is the same as in state $H L$ except there is no payment from the banks.

It turns out that in the example considered it is not possible to keep the insurance companies at their reservation level of utility $E V=0.624$ and make the banks better off if the insurance companies fund the credit risk transfer with the short asset. This is the case for all feasible values of $\tau_{L H}$ and $\tau_{H L}$ and the corresponding optimal choices by banks and insurance companies. The opportunity cost in each state, $\sigma_{L H}(R-1)$, from investing in the short asset rather than in the long asset is simply too large for credit risk transfer to be worthwhile.

If instead of investing $\sigma_{L H}$ in the short asset, the insurance companies invest $\ell_{L H}$ in the long asset so $\tau_{L H}=\ell_{L H} R$, there would not be an opportunity cost $\ell_{L H}(R-1)$ in every state. On the other hand, however, there is a cost in states $H L$ and $L L$, when the insurance companies go bankrupt and must sell the $\ell_{L H}$ long asset at date 1 for a price $P_{H L}=P_{L L}=P_{I L}$. The expected utility of the insured firms' owners in this case is

$$
\begin{aligned}
E V_{\text {long }}= & \left.0.63 V\left(A+\ell_{L H} R+\left(0.5-\ell_{L H}\right) R\right)\right) \\
& +0.07 V\left(0.5+\ell_{L H} P_{I L}+\tau_{H L}+\left(0.5-\ell_{L H}\right) R\right) \\
& \left.+0.27 V\left(A+\left(0.5-\ell_{L H}\right) R\right)\right)+0.03 V\left(0.5+\ell_{L H} P_{I L}+\left(0.5-\ell_{L H}\right) R\right) .
\end{aligned}
$$

Now the firms pay an insurance premium $0.5+\ell_{H L}$ to the insurance companies who invest $X=0.5$ in the short asset and $Y=\ell_{H L}$ in the long asset. The firms then invest the assets that remain after they have paid the insurance premium, $\left(0.5-\ell_{L H}\right)$, in the long asset, and this pays off $\left(0.5-\ell_{L H}\right) R$ in every state. In state $H H$, all the machines that are damaged are repaired using the 0.5 from the short asset. The firms receive $A$ from their machines. There are no credit risk payments so the insurance companies pay the proceeds of their investment in the long asset, $\ell_{L H} R$, out to the firms. In state $H L$, the insurance companies have all their customers claim and go bankrupt. They are unable to repair the assets and distribute the 0.5 that was invested in the short asset together with the $\ell_{L H} P_{I L}$ they get from liquidating their holdings of the long asset to their customers. They receive a credit risk transfer payment of $\tau_{L H}$ from the banks which they also pay out to their customers. In state $L H$, everything is the same as in state $H H$, except that the insurance companies must pay out $\tau_{L H}=\ell_{L H} R$ as a credit risk transfer payment to the banks instead of to their customers. Finally, in state $L L$, everything is the same as in state $H L$ except there is no payment from the banks.

In order to find the optimal credit risk transfer in this case, it is first necessary to find $P_{I L}$. The first issue to consider is that somebody must supply liquidity to this market. In other words, some agents must hold the short asset between dates 0 and 1 in order to have the funds to purchase the long asset that the insurance companies supply to the market when they go bankrupt in states $H L$ and $L L$. If nobody held liquidity, then there would be nobody on the other side of the market and the price of the long asset would fall to zero at date 1 . This would not be an equilibrium though, because by holding a very small amount of cash somebody would be able to enter and buy up all the supplied long asset and make a large profit.

In our framework, the group supplying liquidity is the investors who provide the capital to the banks. In order to be willing to hold this liquidity, they must be able to recoup their 
opportunity cost. Since in states $H H$ and $L H$ when there is no liquidation of assets they end up holding the short asset throughout, they must make a significant profit in states $H L$ and $L L$ when the insurance companies go bankrupt. In other words, the price of the long asset must be low in these states.

To find the price $P_{I L}$ that allows investors to just recover their opportunity cost $\rho=1.5$, suppose they invest 1 in the short term asset at date 0 . As mentioned, in states $H H$ and $L H$, which occur with total probability 0.9 , they will hold the short term asset throughout and receive 1 at date 2 . In states $H L$ and $L L$, which occur with total probability 0.1 , investors will be able to buy $1 / P_{I L}$ of the long asset at date 1 and receive $\left(1 / P_{I L}\right) \times R=$ $\left(1 / P_{I L}\right) \times 1.25$ at date 2 . The price $P_{I L}$ must then satisfy

$$
0.9 \times 1+0.1 \times \frac{1}{P_{I L}} \times 1.25=1.5,
$$

so that

$$
P_{I L}=0.208 \text {. }
$$

We also need to find the price of the long asset $P_{H H}=P_{L H}=P_{I H}$ at date 1 in states $H H$ and $L H$. This is simply equal to

$$
P_{I H}=R=1.25 \text {. }
$$

The reason for this is straightforward. In states $H H$ and $L H$ there is no bankruptcy and no sale of assets. A price equal to $R$ ensures that the investors will hold cash and the insurance companies will hold the long asset between dates 1 and 2 so markets will clear. If $P_{I H}<R$ the investors would want to buy the long asset since it would provide a higher return than cash. If $P_{I H}>R$ the insurance companies would sell the long asset and hold cash until date 2 . The only price at which both the long asset and cash will be held between dates 1 and 2, which is necessary for equilibrium, is $P_{I H}=R$.

Given this pricing of the long asset it can be shown that the optimal values for the transfers and $\ell_{L H}$ are

$$
\tau_{H L}=0.17, \quad \ell_{L H}=0.037, \quad \tau_{L H}=\ell_{L H} R=0.046 .
$$

When the insurance companies go bankrupt in states $H L$ and $L L$, they are forced to liquidate the 0.037 of the long asset they hold to finance the credit risk transfer. In order for the market to clear at $P_{I L}=0.208$, the investors must hold $0.037 \times 0.208=0.008$ in the short asset.

Table 3 gives the full equilibrium with credit risk transfer and also includes the full equilibrium with autarky for the purpose of comparison. It can be seen that the overall effect of credit risk transfer in this case is to make a Pareto improvement in welfare. Credit risk transfer represents a way of sharing risk between the sectors. It is an alternative to bank capital. Since bank capital is a relatively expensive way of sharing risk because of investors' high opportunity cost, the effect of credit risk transfer is to lower the amount of capital banks use. With autarky banks use 0.318 unit of capital, while with credit risk transfer they reduce this to 0.266 and consequently reduce their loans by a corresponding amount. The reduction in the use of relatively expensive capital means the expected consumption of late consumers goes from 1.418 to 1.425 . The improvement in risk sharing allows depositors' expected utility to go from 0.173 to 0.174 while the insurance companies' customers, the firms, remain at 0.624 . 
Table 3

\begin{tabular}{llllll}
\hline Banks & Autarky & CRT & Insurance & Autarky & CRT \\
\hline$c_{1}$ & 1 & 1 & & 1.975 & 1.975 \\
$c_{2 H H}$ & 1.5 & 1.541 & $C_{2 H H}$ & 1.125 & 1.251 \\
$c_{2 H L}$ & 1.5 & 1.211 & $C_{2 H L}$ & 1.975 & 1.929 \\
$c_{2 L H}$ & 1.227 & 1.241 & $C_{2 L H}$ & 1.125 & 1.086 \\
$c_{2 L L}$ & 1.227 & 1.149 & $C_{2 L L}$ & 1.890 & 1.885 \\
$E c_{2}$ & 1.418 & 1.425 & $E C_{2}$ & 0.5 & 0.5 \\
$x$ & 0.5 & 0.5 & $X$ & 0 & 0.037 \\
$y$ & 0 & 0 & $Y=\ell_{L H}$ & Partial \\
$z$ & 0.818 & 0.766 & Insurance & 0 & 0 \\
$e_{0}$ & 0.318 & 0.266 & $E_{0}$ & 0.624 & 0.624 \\
$E U$ & 0.173 & 0.174 & $E V$ & & \\
\hline
\end{tabular}

The Financial System

The Banking Sector

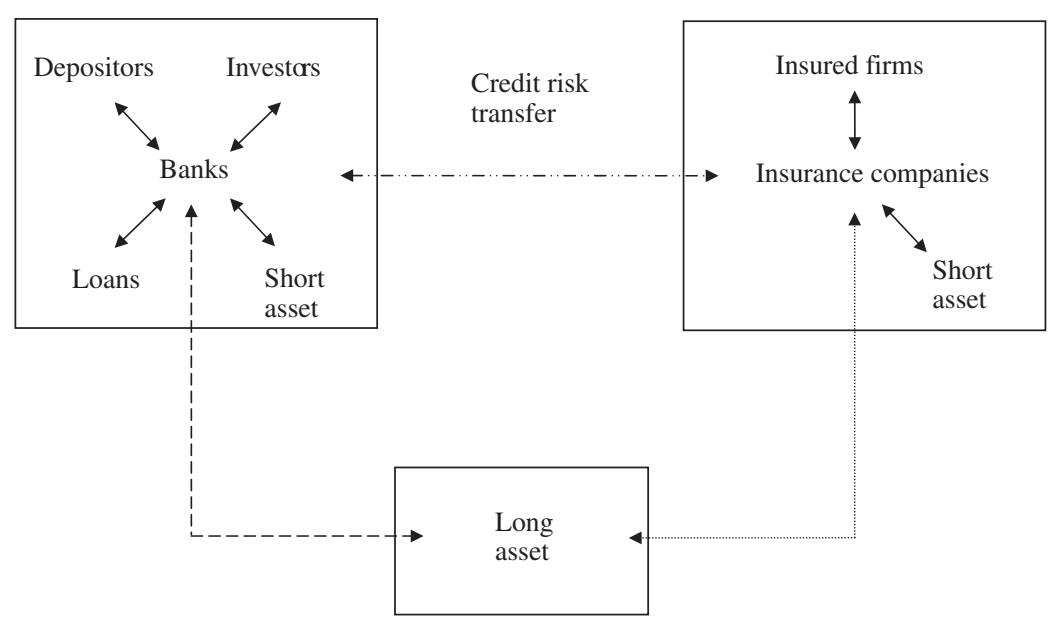

Fig. 1. The financial system.

One important aspect of this equilibrium is that banks do not use the long asset at all. It does not have a high enough return relative to loans to make it worth investing in. This means that when insurance companies liquidate the asset at a low price when they go bankrupt, there is no contagion to the banking sector.

Fig. 1 summarizes the operation of the financial system in the autarky and with beneficial credit risk transfer. Banks always raise funds from depositors and investors and invest in the short term asset and loans. Firms with damageable assets at date 1 buy partial insurance from the insurance companies. In exchange for this insurance, firms pay a premium at date 0 and invest the rest of their initial endowment in the long asset. In the autarky equilibrium, the insurance companies invest the premiums they receive in the short asset, and use the proceeds to meet claims at date 1 . Since returns to the short asset are technologically determined, there are no links between the two sectors. Neither banks nor 
insurance companies find it worthwhile to use the long asset so the dotted lines in the figure are not operational.

The introduction of credit risk transfer modifies the working of the financial system. To facilitate their ability to make a payout to the bank at date 2, insurance companies also start to invest in the long asset, as the line with short dashes in Fig. 1 indicates. Banks choose not to invest in the long asset and the line with long dashes between the bank sector and the market for the long asset is not operative. There is no contagion between the insurance sector and the banking sector, and credit risk transfer is beneficial.

\section{Detrimental credit risk transfer}

So far credit risk transfer has been beneficial because the two sectors hold different assets and there is no contagion to the banking sector when the insurance companies go bankrupt. However, if for some reason banks also start to hold the long term asset, then there is potentially a problem. Banks would be affected by the bankruptcy of the insurance sector and their solvency might be threatened. In terms of Fig. 1 the line with long dashes between the banking sector and the long asset now becomes relevant.

To see how this can happen, we assume that, instead of all facing the same risk, banks are subject to idiosyncratic liquidity risk. With probability 0.5 the proportion of their customers that are early consumers is $\lambda_{i}, i=1,2$, and the proportion of late consumers is $1-\lambda_{i}$ with $\lambda_{1}>\lambda_{2}$. There is no aggregate uncertainty so $0.5 \lambda_{1}+0.5 \lambda_{2}=\lambda$. For simplicity, we assume $\lambda_{1}=1, \lambda_{2}=0$, so these shocks are extreme. Either all of a bank's depositors are early consumers or they are all late consumers. Furthermore, the liquidity risk that banks face is independent of the risk from the payoffs on their loans.

In this new framework, banks hold the long term asset and credit risk transfer can reduce welfare. As before, the insurance companies are forced to liquidate their holdings of the long asset at a low price when they go bankrupt. This now also implies a reduction in the price of the long asset which banks use to hedge their liquidity risk. The banks that are selling the long asset receive a lower amount and are unable to pay their depositors. Within the equilibrium taking prices as given, it is optimal for banks and insurance companies to undertake credit risk transfer. Nevertheless, comparing this equilibrium with the autarkic one with no credit risk transfer, banks are worse off and insurance companies are indifferent.

Note that the insurance sector is not affected by the introduction of idiosyncratic liquidity shocks for banks. Thus, the autarkic equilibrium in the insurance sector is the same as in Section 3.2. We first analyze the new operation of the autarkic banking sector, and consider what happens when credit risk transfer is introduced.

\subsection{The autarkic banking sector with idiosyncratic liquidity shocks}

We focus here on how the idiosyncratic liquidity shocks affect the banking sector in autarky. It is initially assumed as a benchmark that there is no interbank market to allow banks to share liquidity risk and no capital for banks. In this case banks only use the short asset. Then we introduce an interbank market for the long asset which allows banks to hedge the risk associated with the idiosyncratic liquidity shocks they face, and we show banks start to use the long asset. Finally, we introduce capital and show how this also helps 
the idiosyncratic liquidity risk to be shared. We maintain throughout the assumption that loans cannot be liquidated.

\subsubsection{No interbank market or bank capital}

We initially suppose there is no interbank market so banks cannot sell the long asset, and there is no capital so $e_{0}=0$.

As before, banks maximize depositors' expected utility so they choose to invest $x$ in the short asset, $y$ in the long asset and $z$ in loans to solve the following problem:

$$
\begin{aligned}
\operatorname{Max} & 0.5 U\left(c_{1}\right)+0.5\left[0.7 U\left(c_{2 H}\right)+0.3 U\left(c_{2 L}\right)\right] \\
\text { s.t. } & (2) \text { and } \\
& c_{1}=\frac{x}{1}, \\
& c_{2 H}=\frac{x+y R+z B_{H}}{1}, \\
& c_{2 L}=\frac{x+y R+z B_{L}}{1} .
\end{aligned}
$$

The objective function is the same as in (1). The constraints are the per capita consumption of early consumers and of late consumers in states $H$ and $L$. Note that they differ from the case of uniform liquidity shocks. In aggregate there is always 1 unit of depositors. Of these, 0.5 turn out to be early consumers and 0.5 are late consumers. A fraction 0.5 of the banks has all their depositors be early consumers and the remaining 0.5 have all their depositors be late consumers. The measure of the banks with early consumers and the measure of the early consumers are the same so each bank perceives that it has either all depositors be early consumers with probability 0.5 or all late consumers with probability 0.5 . Since there is no interbank market, banks have no opportunity for trade once the state is determined at date 1 . They can only use the assets they have at hand to repay depositors. This implies banks can only give depositors $c_{1}=x / 1$ from the short asset when they are all early consumers. When all depositors are late consumers, loans pay off $B_{H}\left(B_{L}\right)$ in states $H(L)$ and consumers receive $c_{2 H}=x+y R+z B_{H}\left(c_{2 L}=x+y R+z B_{L}\right)$.

The solution to the optimization problem is

$$
\begin{aligned}
& x=1, \quad y=z=0, \\
& c_{1}=c_{2 H}=c_{2 L}=1, \\
& E U=0 .
\end{aligned}
$$

For the particular parameter values of the example, the payoffs on the long asset and the loans are not sufficient to compensate for the fact that they are wasted when all the depositors withdraw early. The reason the long asset and loans are wasted is there are no markets to liquidate them. As a result, the optimal solution is for banks to only use the short asset.

\subsubsection{An interbank market but no bank capital}

We next introduce the possibility for banks to sell the long asset on an interbank market at date 1 if they need to. Suppose the price of the long asset in state $i$ is $P_{i}$ where $i=H, L$. Then banks having all early consuming depositors sell their holdings of the long asset to 
obtain $y P_{i}$ to pay out to their depositors; while banks with all depositors being late consumers buy $x / P_{i}$ of the long asset. This implies each bank solves the following problem at date 0 :

$$
\begin{aligned}
\operatorname{Max} & 0.5\left[0.7 U\left(c_{1 H}\right)+0.3 U\left(c_{1 L}\right)\right]+0.5\left[0.7 U\left(c_{2 H}\right)+0.3 U\left(c_{2 L}\right)\right] \\
\text { s.t. } & (2) \text { and } \\
& c_{1 i}=x+y P_{i} \quad \text { for } i=H, L \\
& c_{2 i}=\left(\frac{x}{P_{i}}+y\right) R+z B_{i} \quad \text { for } i=H, L
\end{aligned}
$$

The first term in the objective function represents the 0.5 probability that a bank's depositors are all early consumers. With probability $0.7(0.3)$ the bank's holdings of the long asset, $y$, can be sold for $P_{H}\left(P_{L}\right)$ and depositors receive $c_{1 H}=x+y P_{H}$ $\left(c_{1 L}=x+y P_{L}\right)$. Loans are wasted because there is no market for them. The second term in the objective function represents the 0.5 probability that all the bank's depositors are late consumers. In this case the bank uses its holdings of the short asset, $x$, to purchase $x / P_{i}$ of the long asset to add to its existing holdings of $y$. In addition depositors receive the payoffs of the bank's loans $z B_{i}$. Thus with probability $0.7(0.3)$ the late depositors receive $c_{2 H}=\left(\left(x / P_{H}\right)+y\right) R+z B_{H}\left(c_{2 L}=\left(\left(x / P_{L}\right)+y\right) R+z B_{L}\right)$.

Since the proceeds from loans are wasted when all depositors turn out to be early consumers, banks do not find it worthwhile to hold loans. It is only worth using the long asset and $z=0$. This implies also that banks' portfolios do not bear any risk and $P_{H}=P_{L}=P$. The only equilibrium price is

$$
P=1 \text {. }
$$

To see this note that if $P<1$ all banks would prefer the short asset between dates 0 and 1 and those with late depositors would attempt to buy the long asset at date 1 . But this cannot be an equilibrium. There would be no supply of the long asset at date 1 because all banks held the short asset between 0 and 1. Similarly if $P>1$, all banks would hold the long asset between dates 0 and 1 , and the banks with early consumers would attempt to sell their holdings at date 1 . There would then be no demand so $P>1$ cannot be an equilibrium price.

Given this pricing of the long asset, the optimal solution to the bank's problem is

$$
\begin{aligned}
& x=y=0.5, \quad z=0, \\
& c_{1}=1, \quad c_{2 H}=c_{2 L}=1.25, \\
& E U=0.112 .
\end{aligned}
$$

The fact that the long asset can be sold in an interbank market means that banks can use it to hedge their liquidity risk. If all their depositors are early consumers, banks sell their holdings of the long asset and use the proceeds together with their holdings of the short asset to pay their depositors. Any holdings of loans would be wasted so they do not find it worth holding these. If all their depositors turn out to be late consumers, banks buy the long asset and thus supply liquidity to the market.

\subsubsection{An interbank market and bank capital}

We now analyze the autarkic equilibrium of the banking sector when there is an interbank market for liquidating the long asset and investors are willing to provide capital. 
Introducing capital now has two effects. As when banks have uniform liquidity risks, capital allows late consuming depositors to share some risk with investors and have higher expected utility. In addition to this though, capital now prevents the waste of a bank's loans when all their depositors want to consume early. Because they are risk neutral, investors provide $e_{0}$ of capital to the banks in return for total expected payoffs that are equivalent. These payoffs consist of the payoffs from the loans when there are all early consumers and a payoff $e_{2}$ in state $i=H$ when there are all late consumers.

The bank's problem is to maximize (9) subject to (6), (10), (11) with $i=L$, and

$$
\begin{aligned}
& c_{2 H}=\left(\frac{x}{P_{H}}+y\right) R+z B_{H}-e_{2}, \\
& \rho e_{0}=0.5\left[0.7\left(z B_{H}\right)+0.3\left(z B_{L}\right)\right]+0.5 \times 0.7 \times e_{2} .
\end{aligned}
$$

This problem is the same as in the case without capital except for the budget constraint (2) being replaced with (6), which has capital included, and two further constraints. The first one, (12), is the per capita consumption of late consuming depositors, and it differs from (11) with $i=H$ because it now allows for the payment $e_{2}$ to the investors providing capital. The second constraint, (13), is the investors' participation constraint. To understand it, recall that each bank faces a probability 0.5 that all its depositors become early consumers and a probability 0.5 of having all late consuming depositors. In the former case, the bank gives the proceeds of its loans to the investors. Thus, investors receive payments $z B_{H}\left(z B_{L}\right)$ with (conditional) probability $0.7(0.3)$, as the first terms on the right-hand side of the constraint shows. When all depositors are instead late consumers, the bank gives a payment $0.7 \times e_{2}$ to the providers of capital as 0.7 is the (conditional) probability that loans pay off $B_{H}$ and the providers of capital are paid $e_{2}$.

In this case the optimal solution is $P=1$ as before and

$$
\begin{aligned}
& x=y=0.459, \quad z=0.160, \quad e_{0}=0.077, \quad e_{2}=0, \\
& c_{1}=0.917, \quad c_{2 H}=1.427, \quad c_{2 L}=1.267, \\
& E U=0.117 .
\end{aligned}
$$

Differently from the optimal solution without capital, it is now worth investing in loans. The reason is that the investors receive the payoffs when the banks customers are early consumers and are willing to provide capital as a result. Thus, loans are no longer wasted and their returns are high enough to induce banks to hold them.

\subsection{Credit risk transfer}

Now that we have considered the banking sector in autarky, we can analyze the effects of credit risk transfer when banks face idiosyncratic liquidity risks. The insurance sector remains the same as before. Given the risks in the two sectors are independent, we have again four possible states with the payoffs shown in Table 4.

As before we focus on credit risk transfer where banks pay $\tau_{H L}$ to insurance companies in state $H L$, and insurance companies transfer $\tau_{L H}$ to banks in state $L H$. As before, it is assumed that banks gain the surplus created by the credit risk transfer.

We first consider whether, taking prices as given at the same levels as in the autarkic solution, it is worth introducing credit risk transfer. With $P=1$ in all states as above, the optimal credit 
Table 4

\begin{tabular}{|c|c|c|c|c|c|}
\hline State & Bank loans & Late depositors & Insurance claims $(\%)$ & Firms & Probability \\
\hline$H H$ & 1.75 & 1.427 & 50 & 1.975 & 0.63 \\
\hline$H L$ & 1.75 & 1.427 & 100 & 1.125 & 0.07 \\
\hline$L H$ & 0.75 & 1.267 & 50 & 1.975 & 0.27 \\
\hline$L L$ & 0.75 & 1.267 & 100 & 1.125 & 0.03 \\
\hline
\end{tabular}

risk transfer has $\tau_{H L}=0.26$. The insurance companies invest $\ell_{L H}=0.075$ in the long asset and make a payment $\tau_{L H}=0.094$. Depositors increase their expected utility to $E U=0.119$, and the firms' owners have the same expected utility of $E V=0.624$ as in autarky. Thus, credit risk transfer is perceived to increase welfare. This, however, cannot be an equilibrium. The insurance companies invest in the long asset to fund the transfer to the banks in state $L H$. In states $H L$ and $L L$ they go bankrupt when the machines of all the firms they insure get damaged. They are forced to liquidate the long asset, and markets no longer clear at $P=1$.

We next solve for the equilibrium with credit risk transfer. The most important feature of this equilibrium is that there is contagion from the insurance sector to the banking sector. The bankrupt insurance companies are forced to sell the long asset in states $H L$ and $L L$. These forced sales drive down the price of the long asset. As a result, the banks that have early consumers and are selling their holdings of the long asset to satisfy their liquidity needs are adversely affected. They can no longer meet their commitments to the early consumers and also go bankrupt. As we shall see, this leads to a Pareto reduction in welfare. The first reason for this is that banks are unable to liquidate their loans because there is no market for them. The second is that the bankrupt banks lose out to the solvent ones, and this reallocation involves inefficient risk sharing.

Banks in this case solve the following optimization problem:

$$
\begin{aligned}
\operatorname{Max} \quad 0.5\left[0.9 U\left(c_{1 I H}\right)+0.1 U\left(c_{1 I L}\right)\right] \\
+0.5\left[0.63 U\left(c_{2 H H}\right)+0.07 U\left(c_{2 H L}\right)+0.27 U\left(c_{2 L H}\right)+0.03 U\left(c_{2 L L}\right)\right]
\end{aligned}
$$

s.t. (6),

$$
\begin{aligned}
& \rho e_{0}= 0.5 \times 0.9 \times z\left(0.7 B_{H}+0.3 B_{L}\right)+0.5 \times 0.27 \times \ell_{L H} \times R+0.5 \times 0.63 \times e_{2}, \\
& c_{1 I H}=x+y P_{I H}, \\
& c_{1 I L}=x+y P_{I L}, \\
& c_{2 H H}=\left(\frac{x}{P_{I H}}+y\right) R+z B_{H}-e_{2}, \\
& c_{2 H L}=\left(\frac{x}{P_{I L}}+y\right) R+z B_{H}-\tau_{H L}-e_{2}, \\
& c_{2 L H}=\left(\frac{x}{P_{I H}}+y\right) R+\tau_{L H}+z B_{L}, \\
& c_{2 L L}=\left(\frac{x}{P_{I L}}+y\right) R+z B_{L} .
\end{aligned}
$$

The objective function of the bank can be understood as follows. Each bank has a 0.5 chance of having all early consuming depositors. The insurance industry is in state $H(L)$ 
with probability $0.9(0.1)$. Banks provide consumption to early consumers $c_{1 H H}=c_{1 L H}=$ $c_{1 I H}\left(c_{1 H L}=c_{1 L L}=c_{1 I L}\right)$ using their holding $x$ of the short asset and by selling the long asset $y$ for $P_{I H}\left(P_{I L}\right)$ so that in total they offer $c_{1 I H}=x+y P_{I H}\left(c_{1 I L}=x+y P_{I L}\right)$. When banks have all late consuming depositors, which occurs also with probability 0.5 , depositors' payoffs depend on the state of both the banking and the insurance sectors. In state $H H$, which occurs with probability 0.63 , these banks use their holding of the short asset to purchase $x / P_{I H}$ of the long asset at date 1 so the total return from the long asset is $\left(\left(x / P_{I H}\right)+y\right) R$. They receive $z B_{H}$ from their loans and pay out $e_{2}$ to shareholders. The same happens in state $H L$, which occurs with probability 0.07 , except that the price for buying the long asset is $P_{I L}$ instead of $P_{I H}$ and banks pay $\tau_{H L}$ to the insurance companies as part of the credit risk transfer. In state $L H$, which occurs with probability 0.27 , the main difference is that banks receive $\tau_{L H}$ from the insurance companies as part of the credit risk transfer. In state $L L$, which occurs with probability 0.03 , there is no credit risk transfer payment so late consuming depositors just consume the returns from the long asset and the loans.

The other constraints, (6) and (14), are the usual budget constraint at date 0 with capital and the investors' participation constraint. In the latter, the first term, $0.5 \times 0.9 \times$ $z\left(0.7 B_{H}+0.3 B_{L}\right)$, represents the expected payoff investors receive when the bank has early consumers and the investors receive the proceeds from the loans. The reason for the 0.9 is that this only happens when the bank remains solvent. The remaining 0.1 of the time the bank goes bankrupt and the loans are worth zero because there is no market for liquidating them. The second term, $0.5 \times 0.27 \times \ell_{L H} \times R$, is the expected payoff to investors when the bank has all early consumers and receives a credit risk transfer from the insurance companies in state $L H$. The final term, $0.5 \times 0.63 \times e_{2}$, is the payment to the investors in state $\mathrm{HH}$.

The method of finding the equilibrium now differs slightly from the previous cases. In particular, we now have to find the equilibrium prices and the solution to the maximization problem simultaneously rather than sequentially. The reason is that there is "cash in the market pricing" in the market for the long asset (see Allen and Gale, 2005b). The buyers of assets find it optimal to use all of their liquidity and the sellers supply all of their long assets so the price is simply the ratio of the liquidity to the amount of the long asset. To calculate it, we then need to know the total liquidity and supply of the long asset in each state, and therefore the optimal values for the transfers and the investments of both banks and insurance companies.

The optimal values for the transfers and $\ell_{L H}$ are

$$
\tau_{H L}=0.192, \quad \ell_{L H}=0.053, \quad \tau_{L H}=0.066 .
$$

Given these values, Table 5 reports the full optimal solution for both banks and insurance companies with credit risk transfer and in autarky for the purpose of comparison.

The values of $x, y$ and $\ell_{L H}$ determine the functioning of the market for the long asset. Since $x=y=0.489$ and $\ell_{L H}=0.053$, the 0.5 banks that have late consumers have liquidity $0.5 \times 0.489=0.245$ at date 1 , while the 0.5 banks that have early consumers have $0.5 \times 0.459=0.245$ of the long asset to sell. In states $H H$ and $L H$ insurance companies do not liquidate their long asset and the equilibrium price is simply

$$
P_{I H}=1 .
$$

In states $H L$ and $L L$, in addition to the banks with early consuming depositors, the bankrupt insurance companies sell 0.053 of the long asset, thus increasing the supply in 
Table 5

\begin{tabular}{llllll}
\hline Banks & Autarky & CRT & Insurance & Autarky & CRT \\
\hline$c_{1 I H}$ & 0.917 & 0.979 & & & \\
$c_{1 I L}$ & 0.917 & 0.892 & & & \\
$c_{2 H H}$ & 1.427 & 1.308 & $C_{2 H H}$ & 1.975 & 1.975 \\
$c_{2 H L}$ & 1.427 & 1.057 & $C_{2 H L}$ & 1.125 & 1.294 \\
$c_{2 L H}$ & 1.267 & 1.326 & $C_{2 L H}$ & 1.975 & 1.909 \\
$c_{2 L L}$ & 1.267 & 1.392 & $C_{2 L L}$ & 1.125 & 1.102 \\
$E c_{2}$ & 1.379 & 1.297 & $E C_{2}$ & 1.890 & 0.583 \\
$x$ & 0.459 & 0.489 & $X$ & 0.5 & 0.053 \\
$y$ & 0.459 & 0.489 & $Y=\ell_{L H}$ & 0 & Partial \\
$z$ & 0.160 & 0.049 & Insurance & Partial & 0 \\
$e_{0}$ & 0.077 & 0.027 & $E_{0}$ & 0 & 0.624 \\
$e_{2}$ & 0 & 0 & & & 0.624 \\
$E U$ & 0.117 & 0.114 & $E V$ & & \\
\hline
\end{tabular}

the market and reducing the price. The market clearing price in states $H L$ and $L L$ is then given by

$$
P_{I L}=\frac{0.245}{0.245+0.053}=0.823 \text {. }
$$

This price is too high to make it worthwhile for investors to provide liquidity to the market as in the case where banks face uniform liquidity shocks, but at the same time it is low enough to also make banks with early consuming depositors go bankrupt in states $H L$ and $L L$.

As a result, the equilibrium with credit risk transfer can be Pareto worse than autarky. As Table 5 shows, the customers of insurance companies obtain the same expected utility of 0.624 in both cases. Banks' depositors obtain 0.117 in autarky and only 0.114 with credit risk transfer. Within the latter equilibrium, taking prices as given, banks' depositors will only obtain expected utility of 0.107 if they do not engage in credit risk transfer so it is definitely worth them undertaking it. Depositors are worse off with credit risk transfer because of the inefficient liquidation of the long asset due to the contagion and the poor risk sharing between banks with early consumers and banks with late consumers. The banks with early consumers go bankrupt and are forced to sell their long asset cheaply. The banks with late consumers make a profit from buying the long asset cheaply. This is bad from an ex ante point of view because the early consumers have the lowest consumption and they are the ones losing out.

Fig. 1 illustrates the key point of the equilibrium with credit risk transfer when banks face idiosyncratic liquidity risk. Without credit risk transfer only banks hold the long asset and they trade it on the interbank market to hedge against liquidity risk. The introduction of credit risk transfer induces the insurance companies to use the long asset as well. This means the two sectors are linked through the market as the dotted lines to the long asset market indicate. The fall in prices caused by the liquidation of insurance companies' long assets result in contagion to the banking sector. The banks that are forced to liquidate their long assets to meet their liquidity needs go bankrupt. 


\section{Concluding remarks}

This paper has shown that credit risk transfer can be beneficial because it improves risk sharing. However, it can also induce contagion and lead to a Pareto reduction in welfare. Financial innovation can thus have somewhat unexpected results. It is necessary to consider all the systemic effects when deciding whether or not it is beneficial.

The examples presented in this paper were developed in the context of banking and insurance. Despite the recent rapid growth in credit risk transfer shown in Table 1, a comparison of the outstanding amounts of credit risk transfer instruments with the total outstanding amounts of bank credit and corporate debt securities shows that they remain small in relative terms. Although credit risk transfer may not pose a systemic problem at the moment, it may do in the future as it continues to grow in importance. Perhaps more important is that this kind of analysis is applicable in many different contexts. The interaction of incomplete markets and the role of liquidity in asset pricing are the key factors for the contagion across sectors. These elements can occur in the context of many financial institutions. Hedge funds have become increasingly important in many markets. They potentially provide a conduit for contagion across many illiquid markets.

We have assumed very simple contractual forms in the insurance industry. More complex contractual forms such as incorporating junior and senior policyholders to allow some claims to be met in the bad state would improve the allocation of resources. However, provided it is not possible to contract around bankruptcy completely, similar results to ours should still hold.

This paper has focused on the private provision of liquidity in markets and has not analyzed the role of central banks in liquidity provision. In markets with limited participation it is likely that central banks will have problems injecting liquidity into the financial system that will reach the required markets and prevent the kind of contagion considered here. The justification used by the Federal Reserve Bank of New York for their intervention in arranging a private sector bailout of Long Term Capital Management in 1998 explicitly used this rationale. The issue of what the precise role of central banks in this kind of situations should be is an interesting question for future research.

\section{References}

Allen, F., Gale, D., 1990. Incomplete markets and incentives to set up an options exchange. In: Polemarchakis, H. (Ed.), Geneva Papers on Risk and Insurance Theory, vol. 15, pp. 7-46 (special issue entitled "The Allocation of Risk with Incomplete Asset Markets").

Allen, F., Gale, D., 1998. Optimal financial crises. Journal of Finance 53, 1245-1284.

Allen, F., Gale, D., 2000a. Financial contagion. Journal of Political Economy 108, 1-33.

Allen, F., Gale, D., 2000b. Optimal currency crises. Carnegie-Rochester Conference Series on Public Policy 53, 177-230.

Allen, F., Gale, D., 2000c. Comparing Financial Systems. MIT Press, Cambridge, MA.

Allen, F., Gale, D., 2004a. Financial intermediaries and markets. Econometrica 72, 1023-1061.

Allen, F., Gale, D., 2004b. Financial fragility, liquidity, and asset prices. Journal of the European Economic Association 2, 1015-1048.

Allen, F., Gale, D., 2005a. Systemic risk and regulation. In: Carey, M., Stulz, R. (Eds.), Risks of Financial Institutions, NBER, to be published.

Allen, F., Gale, D., 2005b. From cash-in-the-market pricing to financial fragility. Journal of the European Economic Association 3, 535-546.

Arping, S., 2004. Credit protection and lending relationships. Working paper, University of Amsterdam. 
BBA, 2002. Credit Derivatives Report, British Bankers Association.

BIS, 2003. Committee on the Global Financial System. Credit Risk Transfer. Bank for International Settlements, Basel, Switzerland.

Cass, D., Citanna, A., 1998. Pareto improving financial innovation in incomplete markets. Economic Theory 11 , 467-494.

Chiesa, G., 2004. Risk transfer, lending capacity and real investment activity. Working paper, Department of Economics, University of Bologna.

Duffee, G., Zhou, C., 2001. Credit derivatives in banking: useful tools for managing risk? Journal of Monetary Economics 48, 25-54.

Elul, R., 1995. Financial innovation in incomplete markets economies with several consumption goods. Journal of Economic Theory 65, 43-78.

Fitch Ratings, 2003. Global Credit Derivatives: Risk Management or Risk? < www.fitchratings.com >, March 10, 2003.

Gale, D., 2003. Financial regulation in a changing environment. In: Courchene, T., Neave, E. (Eds.), Framing Financial Structure in an Information Environment. Kingston, Ontario, John Deutsch Institute for the Study of Economic Policy, Queen's University.

Gale, D., 2004. Notes on optimal capital regulation. In: St-Amant, P., Wilkins, C. (Eds.), The Evolving Financial System and Public Policy. Bank of Canada, Ottawa.

Hart, O., 1975. On the optimality of equilibrium when market structure is incomplete. Journal of Economic Theory 11, 418-433.

Morrison, A., 2005. Credit derivatives, disintermediation and investment decisions. Journal of Business, 78 , 621-647.

Newbery, D., Stiglitz, J., 1984. Pareto inferior trade. Review of Economic Studies 51, 1-12.

Nicolo, A., Pelizzon, L., 2004. Credit derivatives: capital requirements and strategic contracting. Working paper, Department of Economics, University of Padua.

Parlour, C., Plantin, G., 2005. Credit risk transfer. Working paper, Tepper School of Business, Carnegie Mellon University.

Wagner, W., 2005a. The liquidity of bank assets and banking stability. Working paper, Cambridge Endowment for Research in Finance, University of Cambridge.

Wagner, W., 2005b. Interbank diversification, liquidity shortages and banking crises. Working paper, Cambridge Endowment for Research in Finance, University of Cambridge.

Wagner, W., Marsh, I., 2004. Credit risk transfer and financial sector stability. Working paper, Cambridge Endowment for Research in Finance, University of Cambridge. 